\title{
Performance of Bt Cotton Hybrids to Plant Population and Soil Types Under Rainfed Condition
}

\author{
Rajeshwar Malavath*, Ravinder Naik, Pradeep T and Sreedhar Chuhan
}

Acharya N.G Ranga Agricultural University, District Agricultural Advisory and Transfer of Technology Center, KVK,ARS, Adilabad-504 001, RARS, Jagitial , India

\begin{abstract}
Afield experiment was conducted both in black cotton and red chalka soils during kharif 2008-09 and 2009-10 seasons in Adilabad District of Andhra Pradesh at six different locations through farmer's participatory mode to find out the response of BG-II cotton hybrids under two different spacing's in rainfed conditions. These experiments were carried out by the District Agricultural Advisory and Transfer of Technology Center, Adilabad in collaboration with ATMA project functioning at Adilabad. Three cotton hybrids viz., Mallika BG-II (Boll Guard), Rasi BG-II and Paras Brahma BG-II which are most popular among the farmers were sown under two different spacing's in different soils. The data revealed that, hybrids did not differ significantly in plant height, number of sympodial branches/plant, number of bolls/plant, boll weight and seed cottonyield in both the years of testing and also in both the soils. But, spacing's had significantly influenced number of bolls/plant, boll weight and seed cottonyield. However, interaction effect was significant only for plant height. Closer spacing of $60 \times 60 \mathrm{~cm}$ in red chalka soils $\left(2033\right.$ and $\left.2253 \mathrm{~kg} \mathrm{ha}^{-1}\right)$ and $90 \times 60 \mathrm{~cm}$ in BC soils (2300 and $2450 \mathrm{~kg} \mathrm{ha}^{-1}$ ) gave significantly higher seed cottonyield than wider spacing of $90 \times 90 \mathrm{~cm}$ (1500 and $\left.1863 \mathrm{~kg} \mathrm{ha}^{-1}\right)$ and $120 \times 90 \mathrm{~cm}$ (1767 and $\left.1983 \mathrm{~kg} \mathrm{ha}^{-1}\right)$ during both the years of investigation respectively. Thus it is concluded that $\mathrm{Bt}$ hybrids need to be planted with higher plant density to realize good yields.
\end{abstract}

Keywords: Bt Cotton Hybrids; Plant population; Rainfed condition red sandy soils; Black cotton soils

\section{Introduction}

The black cotton soils of Adilabad district of Telangana are moderately deep to very deep, clayey and moderate to moderately well drained with slow permeability and low hydraulic conductivity. Soils have swell shrink characteristic and crack during summer. The moisture retention capacity is high. The early rainfall enters into the soil through cracks and once the cracks are closed the water stagnation occurs due to slow permeability. The Red sandy loam soils have light surface texture and gravelliness with kaolinite clay mineralogy resulting in poor water holding capacity. Surface crusting is common problem in this soil. The low water-holding capacity does not permit post-rainy season cropping without irrigation. Surface soils are denuded and subject to serious erosion problems by runoff process [1].

Cotton is an important fiber crop, which is cultivated in more than 80 countries of the world and play a key role in economic and social affairs of the farming community. In India, nearly 65 per cent of the cotton crop is grown under rainfed conditions on a variety of soils ranging from well drained deep alluvial soils in the north to black clayey soils of varying depth in central region, black, mixed black and red soils in south zone. Cotton is semi-tolerant to salinity and sensitive to water logging and thus prefers well- drained soils [2]. Cotton cultivation in Adilabad district of A.P has gone up after the introduction of Bt Cotton hybrids and is presently grown in an area of about 2.794 lakh hectares (2010-2011) mainly due to the Bt cotton, genetically modified to make insecticidal protein(s) from the soil bacterium Bacillus thuringiensis was first commercialized in 2002 against bollworms. Bt cotton spread rapidly, resulting in greatly increased productivity and reduced insecticide use [3].

Adilabad District is located in Northern Telangana Zone of Andhra Pradesh, situated between $77^{\circ} 46^{\prime}$ and $80^{\circ} 01^{\prime}$ of the Eastern Longitude and $18^{\circ} 40^{\prime}$ and $19^{\circ} 56^{\prime}$ of Northern Latitudes. The soils of the district are predominantly black which constitutes about 80 percent. Cotton is one of the most important commercial crops grown in the district for the last 50 years under rainfed conditions. Cotton yields under rainfed ecosystem are low owing to erratic rainfall and hence the crop suffers from moisture stress during post monsoon season which coincides with flowering and boll development stages. Majority of the farmers in the district do not follow the recommended spacing which is most important agronomic practice under rainfed conditions to get good crop yield.

It is in this context that a systematic study was undertaken to assess the performance of three Bt cotton hybrids in both black cotton (BC) and red chalka soils with two different spacings. Six locations appropriate to farming situation were chosen in the district.

\section{Materials and Methods}

The experiment was conducted on farmer's fields as farmers participatory approach during Kharif 2008-09 and 2009-10 seasons at six different locations such as Mannur, Borigam, Bansupalli, Utnoor, Kerameri and Rajura. An average rainfall of $1093.6 \mathrm{~mm}$ in 2008 and $1137.0 \mathrm{~mm}$ during 2009 season was received in 55 and 57 rainy days respectively.

The experiment was laid out in split plot design with Bt. Hybrids (Mallika BG-II, Rasi BG-II and Paras Brahma BG-II) as main plots and spacing as sub plots with 7 replications. The main plots were same both in BC soils and Red chalka soils. However, spacing varied in subplots.

*Corresponding author: Rajeshwar Malavath, Acharya N.G Ranga Agricultural University, District Agricultural Advisory and Transfer of Technology Center KVK, ARS, Adilabad-504 001, RARS, Jagitial, Tel: +91 8885689290; E-mail: rajeshoct31naik@gmail.com

Received March 05, 2013; Accepted April 07, 2014; Published April 11, 2014

Citation: Malavath R, Naik R, Pradeep T, Chuhan S (2014) Performance of Bt Cotton Hybrids to Plant Population and Soil Types Under Rainfed Condition. Agrotechnol 3: 120. doi:10.4172/2168-9881.1000120

Copyright: (c) 2014 Malavath R, et al. This is an open-access article distributed under the terms of the Creative Commons Attribution License, which permits unrestricted use, distribution, and reproduction in any medium, provided the original author and source are credited. 
In Red chalka soils (sandy clay loam), treatmental spacing adopted was $60 \times 60 \mathrm{~cm}$ which is the recommended spacing and was tested against a spacing of $90 \times 90 \mathrm{~cm}$, adopted by farmers. In BC soils, treatmental spacing was taken as $90 \times 60 \mathrm{~cm}$ which is the recommended spacing and tested against the farmers practice of $120 \times 90 \mathrm{~cm}$.

Three popular hybrids viz., Mallika BG-II, Rasi BG-II and Paras Brahma BG-II were included and the crop was sown in second fort night of June during both the years of study. Standard crop management practices were adopted to raise a good crop. Observations were recorded on yield attributes and the crop was harvested periodically in three pickings and the yield was recorded.

\section{Results and Discussion}

There was no significant difference observed among the hybrids tested for plant height at harvest, number of sympodial branches per plant, number of bolls per plant and seed cotton yield $\left(\mathrm{kg} \mathrm{ha}^{-1}\right)$. With regard to boll weight, pooled mean over two years indicated that Mallika BG II recorded significantly higher boll weight $(5.37 \mathrm{~g})$ compared to Raasi BG II in black cotton soils (Table 1).

Where as in red chalka soils mean over two years (Table 2) indicated that Mallika BG II gave significantly higher plant height $(113.7 \mathrm{~cm})$ compared to Raasi BG II $(109.7 \mathrm{~cm})$ but it was on par with Brahma BG II $(113.5 \mathrm{~cm})$. No significant difference was observed among the varieties tested for number of sympodial branches per plant. The number of bolls per plant and boll weight was significantly higher in Mallika BG II (34.0 and 4.61 respectively) and it was on par with Brahma BG II (32.7 and 4.57 respectively). Similarly there was no significant difference among the varieties for seed cotton yield except in 2009-10 where Mallika BG II exhibited significantly highest seed cotton yield of $2140 \mathrm{~kg} \mathrm{ha}^{-1}$ but it was on par with Brahma BG II (2070 $\mathrm{kg} \mathrm{ha}^{-1}$ ).

\section{Effect of Spacing}

Spacing did not have any significant influence on either the plant height at harvest or the number of sympodial branches per plant during individual years and also mean over two years in black cotton soils (Table 1). Wider spacing of $120 \times 90 \mathrm{~cm}$ produced significantly higher number of bolls per plant (37.5) and boll weight (5.39 g) compared to closer spacing of $90 \times 60 \mathrm{~cm}$ (35.5 and $5.22 \mathrm{~g}$ respectively). It might be due to better aeration and adequate interception of light as well as lesser competition for nutrients due to low plant population per unit area. On the contrary significantly higher seed cotton yield was recorded in closer spacing $\left(2375 \mathrm{~kg} \mathrm{ha}^{-1}\right)$ compared to wider spacing $\left(1874 \mathrm{~kg} \mathrm{ha}^{-1}\right)$.

For red chalka soils closer spacing of $60 \times 60 \mathrm{~cm}$ resulted in significantly higher plant height of $114.8 \mathrm{~cm}$ compared to wider spacing of $90 \times 90 \mathrm{~cm}(109.8 \mathrm{~cm})$ (Table 2). Similar results were observed by Rajendran et al. [4]. The effect of spacing on number of sympodial branches per plant was non significant during individual years and also mean over two years. As regards number of bolls per plant, boll weight and seed cotton yield the effect of spacing is similar in red chalka soils as that of black cotton soils where hybrids in closer spacing had lesser number bolls per plant, lesser boll weight and more seed cottonyield compared to wider spacing. Similar results were obtained by Bhalerao et al. [5] under rainfed condition. The seed cottonyield of black cotton soils obtained was higher when compared to red chalka soils and this could be mainly due to the high water holding capacity in Black cotton soils.

\section{Interaction Effect}

Interaction among the hybrids tested and spacing was non significant for all the parameters in both the soils except for plant height at harvest in both the soils.

Overall, the cotton yields recorded during 2008-09 was comparatively low as compared to 2009-10 even though the quantity of rainfall was high during 2008-09 (894.5 mm with 42 rainy days) might be due to high intensity and uneven distribution. Whereas during 2009-10, though rainfall was comparatively low $(683.0 \mathrm{~mm}$ with 56 rainy days), its uniform distribution for longer period with low intensity enhanced the yield levels (Table 3).

Performance of non Bt cotton hybrids under recommended spacing

\begin{tabular}{|c|c|c|c|c|c|c|c|c|c|c|c|c|c|c|c|}
\hline \multirow{2}{*}{ Treatments } & \multicolumn{3}{|c|}{ Plant height at harvest $(\mathrm{cm})$} & \multicolumn{3}{|c|}{ No. of sympodial branches/plant } & \multicolumn{3}{|c|}{ No. of bolls/plant } & \multicolumn{3}{|c|}{ Boll weight (g) } & \multicolumn{3}{|c|}{ Seed cottonyield (kg/ha) } \\
\hline & 2008-09 & $2009-10$ & Mean & 2008-09 & 2009-10 & Mean & 2008-09 & 2009-10 & Mean & 2008-09 & 2009-10 & Mean & 2008-09 & 2009-10 & Mean \\
\hline \multicolumn{16}{|c|}{ Main plot-Bt. Hybrid } \\
\hline 1. Mallika BG II & 119.0 & 127.5 & 123.2 & 20.5 & 22.5 & 21.5 & 34.5 & 38.5 & 36.5 & 5.25 & 5.50 & 5.37 & 2090 & 2250 & 2170 \\
\hline 2. Raasi BG II & 118.0 & 120.0 & 119.0 & 19.5 & 21.0 & 20.2 & 35.5 & 37.0 & 36.2 & 5.04 & 5.35 & 5.20 & 1960 & 2190 & 2075 \\
\hline 3. Brahma BG II & 121.0 & 122.5 & 121.7 & 20.5 & 21.5 & 21.0 & 35.5 & 38.0 & 36.7 & 5.25 & 5.42 & 5.34 & 2050 & 2207 & 2129 \\
\hline Mean & 119.3 & 123.3 & 121.3 & 20.2 & 21.7 & 20.9 & 35.2 & 37.8 & 36.5 & 5.18 & 5.42 & 5.30 & 2033 & 2216 & 2125 \\
\hline $\mathrm{SEm} \pm$ & 3.6 & 2.9 & 2.5 & 0.88 & 0.73 & 0.59 & 0.79 & 0.97 & 0.69 & 0.09 & 0.01 & 0.04 & 65.0 & 57.0 & 43.0 \\
\hline $\mathrm{SEd} \pm$ & 5.1 & 4.1 & 3.5 & 1.24 & 1.04 & 0.84 & 1.11 & 1.38 & 0.98 & 0.13 & 0.02 & 0.06 & 91.0 & 81.0 & 60.0 \\
\hline $\mathrm{CD}$ (at 5\%) & NS & NS & NS & NS & NS & NS & NS & NS & NS & NS & 0.05 & 0.14 & NS & NS & NS \\
\hline \multicolumn{16}{|c|}{ Sub plots-Spacing } \\
\hline 1. $90 \times 60 \mathrm{~cm}$ & 121.7 & 123.3 & 122.5 & 19.6 & 21.0 & 20.3 & 34.3 & 36.6 & 35.5 & 5.10 & 5.33 & 5.22 & 2300 & 2450 & 2375 \\
\hline 2. $120 \times 90 \mathrm{~cm}$ & 117.0 & 123.3 & 120.2 & 20.6 & 22.3 & 21.5 & 36.0 & 39.0 & 37.5 & 5.26 & 5.52 & 5.39 & 1767 & 1983 & 1874 \\
\hline Mean & 119.4 & 123.3 & 121.4 & 20.1 & 21.7 & 20.9 & 35.2 & 37.8 & 36.5 & 5.2 & 5.4 & 5.3 & 2034 & 2216 & 2125 \\
\hline $\mathrm{SEm} \pm$ & 4.7 & 4.4 & 2.7 & 0.98 & 1.11 & 0.72 & 0.58 & 0.75 & 0.43 & 0.08 & 0.07 & 0.04 & 64.6 & 44.6 & 29.1 \\
\hline $\mathrm{SEd} \pm$ & 6.7 & 6.3 & 3.8 & 1.39 & 1.57 & 1.02 & 0.82 & 1.06 & 0.61 & 0.11 & 0.10 & 0.07 & 91.3 & 63.0 & 41.2 \\
\hline CD (at 5\%) & NS & NS & NS & NS & NS & NS & 1.74 & 2.23 & 1.29 & 0.02 & 0.20 & 0.14 & 192.0 & 132.5 & 86.6 \\
\hline \multicolumn{16}{|l|}{ Interactions } \\
\hline $\mathrm{SEm} \pm$ & 3.8 & 3.6 & 2.2 & 0.8 & 0.9 & 0.6 & 0.5 & 0.6 & 0.3 & 0.1 & 0.1 & 0.0 & 51.8 & 35.7 & 23.3 \\
\hline $\mathrm{SEd} \pm$ & 5.3 & 5.0 & 3.1 & 1.1 & 1.3 & 0.8 & 0.7 & 0.9 & 0.5 & 0.1 & 0.1 & 0.1 & 73.2 & 50.5 & 33.0 \\
\hline $\mathrm{CD}($ at $5 \%)$ & 11.2 & 10.7 & 6.5 & NS & NS & NS & 1.4 & NS & NS & NS & NS & NS & NS & NS & NS \\
\hline CV (\%) & 12.9 & 11.8 & 12.3 & 15.8 & 16.6 & 16.2 & 15.4 & 16.4 & 15.9 & 14.7 & 14.1 & 13.4 & 10.3 & 16.5 & 13.4 \\
\hline
\end{tabular}

Table 1: Effect of spacing on number of bolls per plant, boll weight and seed yield of cotton in Black cotton soils Kharif 2008-09 and 2009-10. 
Citation: Malavath R, Naik R, Pradeep T, Chuhan S (2014) Performance of Bt Cotton Hybrids to Plant Population and Soil Types Under Rainfed Condition. Agrotechnol 3: 120. doi:10.4172/2168-9881.1000120

Page 3 of 3

\begin{tabular}{|c|c|c|c|c|c|c|c|c|c|c|c|c|c|c|c|}
\hline \multirow{2}{*}{ Treatments } & \multicolumn{3}{|c|}{ Plant height at harvest $(\mathrm{cm})$} & \multicolumn{3}{|c|}{ No. of sympodial branches/plant } & \multicolumn{3}{|c|}{ No. of bolls/plant } & \multicolumn{3}{|c|}{ Boll weight (g) } & \multicolumn{3}{|c|}{ Seed cottonyield (kg/ha) } \\
\hline & 2008-09 & $2009-10$ & Mean & 2008-09 & 2009-10 & Mean & 2008-09 & 2009-10 & Mean & 2008-09 & 2009-10 & Mean & 2008-09 & 2009-10 & Mean \\
\hline \multicolumn{16}{|c|}{ Main plot-Bt. Hybrid } \\
\hline 1. Mallika BG II & 107.5 & 120.0 & 113.7 & 19.5 & 20.5 & 20.0 & 31.5 & 36.5 & 34.0 & 4.40 & 4.81 & 4.61 & 1755 & 2140 & 1948 \\
\hline 2. Raasi BG II & 104.5 & 115.0 & 109.7 & 19.5 & 19.0 & 19.2 & 29.5 & 35.0 & 32.2 & 4.41 & 4.55 & 4.48 & 1725 & 1965 & 1845 \\
\hline 3. Brahma BG II & 110.0 & 117.0 & 113.5 & 18.5 & 18.5 & 18.5 & 31.0 & 34.5 & 32.7 & 4.45 & 4.70 & 4.57 & 1820 & 2070 & 1945 \\
\hline Mean & 107.3 & 117.3 & 112.3 & 19.2 & 19.3 & 19.2 & 30.7 & 35.3 & 33.0 & 4.42 & 4.69 & 4.55 & 1767 & 2058 & 1913 \\
\hline $\mathrm{SEm} \pm$ & 0.5 & 2.8 & 1.5 & 1.22 & 0.9 & 0.63 & 0.77 & 0.67 & 0.54 & 0.05 & 0.06 & 0.03 & 54.0 & 53.0 & 48.0 \\
\hline $\mathrm{SEd} \pm$ & 0.7 & 4.0 & 2.1 & 1.72 & 1.27 & 0.9 & 1.09 & 0.95 & 0.77 & 0.07 & 0.09 & 0.05 & 76.0 & 75.0 & 68.0 \\
\hline CD (at 5\%) & 1.5 & NS & 4.5 & NS & NS & NS & NS & 2.06 & 1.67 & NS & 0.18 & 0.11 & NS & 163.3 & NS \\
\hline \multicolumn{16}{|l|}{ Sub plots-Spacing } \\
\hline 1. $90 \times 60 \mathrm{~cm}$ & 110.0 & 119.7 & 114.8 & 18.3 & 19.0 & 18.7 & 29.0 & 34.0 & 31.5 & 4.23 & 4.61 & 4.42 & 2033 & 2253 & 2143 \\
\hline 2. $120 \times 90 \mathrm{~cm}$ & 104.7 & 115 & 109.8 & 20.0 & 19.6 & 19.8 & 32.3 & 36.6 & 34.5 & 4.61 & 4.77 & 4.69 & 1500 & 1863 & 1682 \\
\hline Mean & 107.4 & 117.4 & 112.3 & 19.2 & 19.3 & 19.2 & 30.7 & 35.3 & 33.0 & 4.4 & 4.7 & 4.6 & 1767 & 2058 & 1913 \\
\hline $\mathrm{SEm} \pm$ & 1.5 & 2.8 & 1.34 & 1.11 & 0.93 & 0.65 & 0.49 & 0.78 & 0.35 & 0.04 & 0.05 & 0.04 & 40.7 & 58.9 & 35.8 \\
\hline $\mathrm{SEd} \pm$ & 2.2 & 4 & 1.89 & 1.57 & 1.32 & 0.91 & 0.69 & 1.1 & 0.49 & 0.06 & 0.07 & 0.06 & 57.5 & 83.3 & 50.6 \\
\hline CD (at 5\%) & 4.7 & NS & 3.99 & NS & NS & NS & 1.46 & 2.32 & 1.04 & 0.13 & 0.15 & 1.30 & 121.0 & 175.1 & 106.4 \\
\hline \multicolumn{16}{|l|}{ Interactions } \\
\hline $\mathrm{SEm} \pm$ & 1.2 & 2.3 & 1.1 & 0.9 & 0.7 & 0.5 & 0.4 & 0.6 & 0.3 & 0.03 & 0.04 & 0.03 & 32.6 & 47.2 & 28.7 \\
\hline $\mathrm{SEd} \pm$ & 1.8 & 3.2 & 1.5 & 1.3 & 1.1 & 0.7 & 0.6 & 0.9 & 0.4 & 0.04 & 0.06 & 0.05 & 46.1 & 66.8 & 40.6 \\
\hline CD (at 5\%) & 3.8 & 6.8 & 3.2 & NS & NS & NS & NS & NS & NS & 0.10 & NS & NS & NS & NS & NS \\
\hline CV (\%) & 14.8 & 17.9 & 16.3 & 18.8 & 15.7 & 17.2 & 15.2 & 17.2 & 16.2 & 13.1 & 13.5 & 13.3 & 17.5 & 19.3 & 18.4 \\
\hline
\end{tabular}

Table 2: Effect of spacing on number of bolls per plant, boll weight and seed yield of cotton in Red chalka soils Kharif 2008-09 and 2009-10

\begin{tabular}{|l|c|c|c|c|}
\hline \multirow{2}{*}{ Month } & \multicolumn{2}{|c|}{$\mathbf{2 0 0 8 - 0 9}$} & \multicolumn{2}{c|}{$\mathbf{2 0 0 9 - 1 0}$} \\
\cline { 2 - 5 } & $\begin{array}{c}\text { Total Rainfall } \\
\text { Received (mm) }\end{array}$ & $\begin{array}{c}\text { No. of Rainy } \\
\text { days }\end{array}$ & $\begin{array}{c}\text { Total Rainfall } \\
\text { Received (mm) }\end{array}$ & $\begin{array}{c}\text { No. of Rainy } \\
\text { days }\end{array}$ \\
\hline June & 126.3 & 6 & 101.2 & 8 \\
\hline July & 220 & 14 & 166.5 & 18 \\
\hline August & 378.8 & 16 & 185.3 & 15 \\
\hline September & 141.87 & 4 & 122.5 & 5 \\
\hline October & 12.2 & 1 & 39.6 & 5 \\
\hline November & 14 & 1 & $\mathbf{2 6 . 4}$ & 3 \\
\hline December & 0.0 & 0 & - & 0 \\
\hline January & 0.0 & 0 & $\mathbf{1 6 . 1}$ & 1 \\
\hline February & 0.0 & 0 & 7.5 & 1 \\
\hline March & 2.0 & 0 & 0.8 & 0 \\
\hline April & 0.0 & 0 & 0.0 & 0 \\
\hline May & 0.5 & 0 & 1.0 & 0 \\
\hline Total & $\mathbf{8 9 4 . 5}$ & $\mathbf{4 2}$ & $\mathbf{6 8 3 . 0}$ & $\mathbf{5 6}$ \\
\hline
\end{tabular}

Table 3: Rainfall of the district during the year 2008-09 and 2009-10.

of $90 \times 90 \mathrm{~cm}$ or $120 \times 90 \mathrm{~cm}$ even under rainfed situation during eighties was more than satisfactory due to better control of sucking pests and boll worms with predicted behavior of weather conditions particularly the rainfall. However, due to fluctuations in weather parameters, spread of cotton crop to newer areas and indiscriminate use of insecticides leading to resurgence of certain pests drastically affected the yield potential of hybrids in due course of time. It was at this juncture i.e., a decade back Bt cotton hybrids were introduced and as a result the menace of boll worms was over come and relatively good retention of bolls was witnessed. Retention of maximum number of bolls also sometimes made the plants to change their growth habit (determinate/indeterminate) according to the prevailing seasonal conditions. Under closer spacing due to reduced canopy and more number of plants per unit area plants exhibited determinate growth particularly when monsoon ceased early and the farmers got good yields.

Therefore due to these frequent changes in macro and micro weather conditions the performance of Bt hybrids becomes unpredictable and the farmers suffered huge losses or benefits. It is in this context that the results of the present experimentation have got immense practical utility. Thus it is suggested to adopt closer spacing in both types of soil as it provides better opportunity for Bt hybrids to express their potential under rainfed conditions in Adilabad district.

\section{Acknowledgement}

The authors are thankful to authorities of Acharya N.G Ranga Agricultural University, Hyderabad and ATMA Project Adilabad, Andhra Pradesh, India for their technical as well as financial support during the course of investigation.

\section{References}

1. Ground Water Information (2007) Central Ground Water Board Ministry of Water Resources. Government of India, Adilabald District, Andhra Pradesh southern region, Hyderabad: 1-38.

2. Revolution in Indian Cotton (2009) Directorate of Cotton Development Department of Agriculture \& Cooperation. Ministry of Agriculture, Govt. of India, Mumbai, National Center of Integrated Pest Management ICAR, Pusa Campus, New Delhi: 1-59.

3. Asia-Pacific Consortium on Agricultural Biotechnology (APCoAB) (2009) Bt cotton in India-A status report. Asia-Pacific Consortium on Agricultural Biotechnology, New Delhi, India: 1-37.

4. RajendranK, Mohamed Amanullah M, Vaiyapuri K (2010) Effect of Spacing and Nutrient Levels on Bt Cotton. Madras Agric J97:379-380.

5. Bhalerao PD, Patil BR, Ghatol PU, Gawande PP (2010) effect of spacing and fertilizer levels on seed cotton yield under rainfed condition. Indian J Agric Res 44: 74-76. 